\title{
Effect of Different Levels of Phosphorus and Biofertilizer Combination on Growth and Yield of Kharif Greengram (Vigna radiata L.)
}

\author{
Pole Shiva Kiran*, Joy Dawson, Sunnam Hemanth Kumar \\ and Bareddy Narendranath Reddy
}

\begin{abstract}
Department of Agronomy, Sam Higginbottom University of Agriculture Technology and Sciences, Prayagraj, Uttar Pradesh, India
\end{abstract}

*Corresponding author

\section{A B S T R A C T}

\section{Keywords}

Greengram, Biofertilizers, Growth and Yield

Article Info

Accepted: 20 October 2020 Available Online: 10 November 2020
The field experiment was conducted in Kharif season comprised of Phosphorus levels (30, 40, 50) kg/ha and Biofertilizers [(PSB (Soil application-25 kg/ha.), Rhizobium (Seed inoculation-200gm/10 kg/seed)]. The experiment was conducted in Randomized Block Design with 3 Replications and 10 Treatments Application of $40 \mathrm{~kg} \mathrm{P}_{2} \mathrm{O}_{5}+25 \mathrm{~kg}$ PSB was recorded maximum Plant height $(27.94 \mathrm{~cm})$, Nodules (20.03), Dry weight (1.99 g), Pods per Plant (45.63) and Grain yield was $658.33 \mathrm{~kg} / \mathrm{ha}$. and maximum benefit cost ratio was recorded in the treatment combination of $40 \mathrm{~kg} \mathrm{P}_{2} \mathrm{O}_{5}+$ Rhizobium was 2.16 .

\section{Introduction}

Pulses are the important crops in our country and main source of vegetable and the major protein component of Indian diet comes from pulses and easily digestible and cheaper has high biological values and it contains $132 \mathrm{mg}$ of calcium, $6.74 \mathrm{mg}$ iron, $189 \mathrm{mg}$ magnesium, $367 \mathrm{mg}$ of phosphorus, with a good vitamins and proteins they require less water requirement and pulses are cheaper than meat and they often called as Poor man's crop. Greengram can be cultivated in arid and semiarid regions of the country and grown on a variety of soil and climatic conditions as it is tolerant to drought and greengram contains about $25 \%$ Protein and it is rich in lysine which is deficient in cereal grains Being legume it has the capacity to fix nitrogen and helps in preventing soil erosion and restores soil fertility and Mungbean responds favorably to phosphorus fertilizer (Chovati et al., 1993).

\section{Materials and Methods}

The experiment was carried out during Kharif season of 2019 at Crop Research Farm, Department of Agronomy, Naini Agricultural Institute, SHUATS, Prayagraj which is 
located at 25o 24' 42" N latitude, 81o 50' 56" E longitude and $98 \mathrm{~m}$ altitude above the mean sea level. This area is situated on the right side of the river Yamuna by the side of Allahabad Rewa Road about $5 \mathrm{~km}$ away from Prayagraj (Allahabad) and carried out with 10 treatments and 3replications were carried out along with three levels of Phosphorus $(30,40,50)$ NPK $\mathrm{kg} / \mathrm{ha}$ and 2 biofertilizers (PSB(Soil application-25kg/ha,) Rhizobium (Seed inoculation $200 \mathrm{gram} / 10 \mathrm{~kg}$ seed.) with the treatment combination of following treatments $\mathrm{T}_{1}: 30 \mathrm{kgP}_{2} \mathrm{O}_{5}+25 \mathrm{kgPSB}$, $\mathrm{T}_{2}: 30 \mathrm{kgP}_{2} \mathrm{O}_{5}+$ Rhizobium, $\mathrm{T}_{3}: 30 \mathrm{kgP}_{2} \mathrm{O}_{5}+$ $25 \mathrm{kgPSB}+$ Rhizobium, $\mathrm{T}_{4}: 40 \mathrm{kgP}_{2} \mathrm{O}_{5}+$ 25kgPSB, $\mathrm{T}_{5}: 40 \mathrm{kgP}_{2} \mathrm{O}_{5}+$ Rhizobium, $\mathrm{T}_{6}: 40 \mathrm{kgP}_{2} \mathrm{O}_{5}+25 \mathrm{kgPSB}+$ Rhizobium, $\mathrm{T}_{7}: 50 \mathrm{kgP}_{2} \mathrm{O}_{5}+25 \mathrm{kgPSB}, \mathrm{T}_{8}: 50 \mathrm{kgP}_{2} \mathrm{O}_{5}+$ Rhizobium, $\mathrm{T}_{9}$ : $50 \mathrm{kgP}_{2} \mathrm{O}_{5}+25 \mathrm{~kg}$ PSB + Rhizobium, $\mathrm{T}_{10}$ : Control (20:40:20) NPK $\mathrm{kg} / \mathrm{ha}$. and the seeds were sown with the recommended agronomic practices. and seed rate was $20 \mathrm{~kg} / \mathrm{ha}$, and soil application with PSB $25 \mathrm{~kg} / \mathrm{ha}$ and then seeds were inoculated with rhizobium culture $20 \mathrm{gram} / 10 \mathrm{~kg}$. It is sown in various plots and all the fertilizers were applied at the basal dose (20:40:20) NPK $\mathrm{kg} / \mathrm{ha}$ and plot size was $3 \times 3 \mathrm{~m}$, the plants are spaced at $30 \times 10 \mathrm{~cm}$ followed by line sowing and parameters like Plant height, nodules, dryweight, post harvest observations (Number of Pods/ Plant, Seed yield kg/ha and $\mathrm{B}: \mathrm{C}$ ratio and calculated on the basis of benefit cost ratio are calculated by dividing gross return and cost of cultivation. The data were analyzed by ANOVA and significance of different sources of variations were tested by error means of square of Fisher's F test at probability significance level of 0.05 .

\section{Results and Discussion}

\section{Plant height}

The maximum plant height was recorded in the treatment combination $40 \mathrm{~kg}$ P2O5+25 kg
PSB was $27.94 \mathrm{~cm}$ and statically at par with $40 \mathrm{~kg}$ P2O5 + Rhizobium this might be due to the increase in such case may be due to increased cell division and elongation on one hand and also genetic character of the variety Prasad, S.K et al., (2014).

\section{No. of Nodules/plant}

At 60 DAS the maximum number of root nodules/plant was recorded in the treatment combination of $40 \mathrm{Kg} \mathrm{P}_{2} \mathrm{O}_{5}+25 \mathrm{Kg}$ PSB was 20.03 was significantly higher among all the treatments and statically at par with $30 \mathrm{~kg}$ $\mathrm{P}_{2} \mathrm{O}_{5}+25 \mathrm{~kg}$ PSB, $30 \mathrm{~kg} \mathrm{P}_{2} \mathrm{O}_{5}+$ Rhizobium, $40 \mathrm{~kg} \mathrm{P}_{2} \mathrm{O}_{5}+$ Rhizobium, $40 \mathrm{~kg} \mathrm{P}_{2} \mathrm{O}_{5}+25 \mathrm{~kg}$

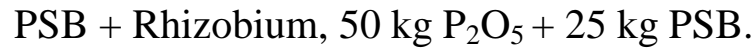

The application of phosphate solubilizing bacteria proved to be effective in developing significantly higher number of root nodules/plant. It has beneficial effects on nodulation, root development, growth and also hastens the maturity quality of crop produce (Choudhary et al., 2015). Such increase in nodulation, root and growth and might be due to increase in number of nodules which might have supplied sufficient nitrogen by nitrogen fixation and finally enhance productivity of greengram (Prasad et al., 2014).

\section{Dry-weight}

The maximum dry weight $\mathrm{w}$ recorded in 60 DAS were in the treatment combination was $40 \mathrm{~kg} \mathrm{P}_{2} \mathrm{O}_{5}+25 \mathrm{~kg}$ PSB was 1.99 was recorded significantly higher among all the treatments and statically at par with, 30kg $\mathrm{P}_{2} \mathrm{O}_{5}+25 \mathrm{~kg}$ PSB,30 kg $\mathrm{P}_{2} \mathrm{O}_{5}+$ Rhizobium,30 $\mathrm{kg} \mathrm{P}_{2} \mathrm{O}_{5}+25 \mathrm{~kg}$ PSB + Rhizobium, $50 \mathrm{~kg}$ $\mathrm{P}_{2} \mathrm{O}_{5}+25 \mathrm{~kg} \mathrm{PSB}, 50 \mathrm{~kg} \mathrm{P}_{2} \mathrm{O}_{5}+25 \mathrm{~kg} \mathrm{PSB}+$ Rhizobium and minimum dry weight recorded in 60 DAS was recorded in treatment combination of Control (20:40:20) NPK $\mathrm{Kg} /$ ha was 1.15 (Table 1). 
Table.1 Effect of different levels of phosphorus and biofertilizer combination on growth and yield attributes of greengram

\begin{tabular}{|c|c|c|c|c|c|c|}
\hline Treatments & $\begin{array}{c}\text { Plant } \\
\text { height } \\
\text { (cm) }\end{array}$ & $\begin{array}{l}\text { Nodule } \\
\text { s/ Plant }\end{array}$ & $\begin{array}{c}\text { Dry } \\
\text { weight } \\
\text { (gm) }\end{array}$ & Pods/plant & $\begin{array}{c}\text { Grain yield } \\
\text { (kg/ha) }\end{array}$ & $\mathrm{B}: \mathrm{C}$ ratio \\
\hline $30 \mathrm{~kg} \mathrm{P}_{2} \mathrm{O}_{5}+25 \mathrm{~kg}$ PSB & 23.20 & 18.56 & 1.59 & 44.33 & 540 & 1.75 \\
\hline 30 kg $\mathrm{P}_{2} \mathrm{O}_{5}+\mathrm{Rhizobium}$, & 23.35 & 18.78 & 1.76 & 42.13 & 470 & 1.58 \\
\hline $30 \mathrm{~kg} \mathrm{P}_{2} \mathrm{O}_{5}+25 \mathrm{~kg}$ PSB +Rhizobium & 22.65 & 17.11 & 1.67 & 35.33 & 563.33 & 1.79 \\
\hline $40 \mathrm{~kg} \mathrm{P}_{2} \mathrm{O}_{5}+25 \mathrm{~kg}$ PSB & 27.94 & 20.03 & 1.99 & 45.63 & 658.33 & 2.12 \\
\hline $40 \mathrm{~kg} \mathrm{P}_{2} \mathrm{O}_{5}+$ Rhizobium & 26.15 & 19.00 & 1.40 & 41.60 & 643.33 & 2.16 \\
\hline $40 \mathrm{~kg} \mathrm{P}_{2} \mathrm{O}_{5}+25 \mathrm{~kg} \mathrm{PSB}+$ Rhizobium & 22.43 & 19.22 & 1.43 & 37.47 & 563.33 & 1.78 \\
\hline $50 \mathrm{~kg} \mathrm{P}_{2} \mathrm{O}_{5}+25 \mathrm{~kg}$ PSB & 23.70 & 18.11 & 1.60 & 36.43 & 570 & 1.83 \\
\hline $50 \mathrm{~kg} \mathrm{P}_{2} \mathrm{O}_{5}+$ Rhizobium, & 23.63 & 17.20 & 1.49 & 37.67 & 490 & 1.63 \\
\hline $50 \mathrm{~kg} \mathrm{P}_{2} \mathrm{O}_{5}+25 \mathrm{~kg}$ PSB +Rhizobium & 22.92 & 17.33 & 1.59 & 35.60 & 590 & 1.86 \\
\hline Control (20:40:20) NPK kg/ha & 19.98 & 13.83 & 1.15 & 39.00 & 453 & 1.55 \\
\hline SEm \pm & 1.05 & 0.56 & 0.14 & 2.22 & 38.59 & 0.13 \\
\hline C.D $(p=0.05)$ & 3.12 & 2.56 & 0.42 & 6.61 & 114.65 & 0.38 \\
\hline
\end{tabular}


The plants attained more vigorous with different combinations of Phosphorus as compared to control due to adequate supply and availability of nitrogen, phosphorus and potassium and spacing balanced combination increased root dry weight of plant (Erman et al., 2009).

\section{Pods/plant}

Maximum Pods/plant recorded in the treatment combination of $40 \mathrm{~kg} \mathrm{P}_{2} \mathrm{O}_{5}+$ $25 \mathrm{kgPSB}$ ) is 45.63 was significantly higher among all treatments and atpar with $30 \mathrm{~kg}$ $\mathrm{P}_{2} \mathrm{O}_{5}+25 \mathrm{~kg} \mathrm{PSB}, 30 \mathrm{~kg} \mathrm{P}_{2} \mathrm{O}_{5}+$ Rhizobium, $40 \mathrm{~kg} \mathrm{P}_{2} \mathrm{O}_{5}+$ Rhizobium. This might be due to Higher number of pods/plant might have been possible due to more vigor and strength attained by the plant as result of better photosynthetic activity with sufficient availability of light and supply of nutrients in a balanced quantity.(Richardson et al., 1957).

\section{Grain yield}

The maximum grain yield was recorded in the treatment combination of $40 \mathrm{~kg} \quad \mathrm{P}_{2} \mathrm{O}_{5}+$ $25 \mathrm{kgPSB}$ ) is $658.33 \mathrm{~kg} / \mathrm{ha}$ was significantly higher among all treatments and at par with30 kg $\mathrm{P}_{2} \mathrm{O}_{5}+25 \mathrm{~kg}$ PSB+ Rhizobium, $40 \mathrm{~kg} \mathrm{P}_{2} \mathrm{O}_{5}$ + Rhizobium, $40 \mathrm{~kg} \mathrm{P}_{2} \mathrm{O}_{5}+25 \mathrm{~kg}$ PSB + Rhizobium, $50 \mathrm{~kg} \mathrm{P}_{2} \mathrm{O}_{5}+25 \mathrm{~kg}$ PSB, $50 \mathrm{~kg}$ $\mathrm{P}_{2} \mathrm{O}_{5}+25 \mathrm{~kg}$ PSB + Rhizobium. This might due to the increase in yield by the application of $40 \mathrm{~kg} \mathrm{P}_{2} \mathrm{O}_{5}$ per hectare in combination with PSB observed more yield (Rekha et al., 2018).

\section{Benefit cost ratio}

The highest benefit cost ratio was found in treatment combination of $40 \mathrm{~kg} \quad \mathrm{P}_{2} \mathrm{O}_{5}+$ Rhizobium was 2.16 (Shubhandu Mandal et al., 2005). It may be concluded that and treatment with $40 \mathrm{~kg} \mathrm{P}_{2} \mathrm{O}_{5}+$ Rhizobium was recorded benefit cost ratio 2.16 and treatment with $40 \mathrm{~kg} \mathrm{P}_{2} \mathrm{O}_{5}+25 \mathrm{~kg}$ PSB recorded highest grain yield $(658.33 \mathrm{~kg} / \mathrm{ha})$ which may be more profitable regarding grain yield. Hence variety SAMRAT can be recommended to the farmers.

\section{Acknowledgements}

I express my gratitude to my advisor Prof. (Dr.) Joy Dawson for constant support, guidance and for his valuable suggestions for improving the quality of this work. I am indebted to Prof. (Dr.) Thomas Abraham who has been a constant source of inspiration and all the faculty members of Department of Agronomy, SHUATS, Prayagraj, Uttar Pradesh (U.P), India for providing necessary facilities, for their cooperation, encouragement and support.

\section{References}

Chovati, P.N., Ahlawat, R..P.S. and Trivedi, S.J.(1993).Growth and yield summer mung bean (Vigna radiata L.) as affected by different dates of sowing, Rhizobium inoculation and level $\mathrm{s}$ of Phosphorus. Indian Journal of Agronomy. 38(3):492-494.

Erman, M. Yildrin, Btogay, N. cig F.(2009). Effect of Phosphorus application and Rhizobium inoculation on the yield nodulation and nutrient uptake in the field pea (Pisum sativum L.) Journal of Animal and Veterinary Advances. 8(2):301-304.

Fisher, R.A. 1921. On the probable error of a coefficient of correlation deduced from a small sample. Metron: Pp. 13-32.

Karnavet Rekha, Pavaya, R.P., Malav, J.K., Neha Choudhary, Patel, I.M., and Patel, J.K. (2018). Effect of FYM, Phosphorus and PSB on yield nutrient content and uptake by (Vigna radiata L.) on loamy sand soils. International Journal of Chemical studies. 6(2):1026- 
1029.

Prasad, S.K., Singh, M.K. and Singh, J. (2014). Response of Rhizobium inoculation and phosphorus levels on mungbean (Vigna radiata L.) under guava-based agri-hortisystem. The Bioscan, 9: 557-560.

Richardson. D.A. and Garred, E.H. (1954).

The influence of combined nitrogen on nodulation and nitrogen fixation. Canadian Journal of Plant Science. 20(1):87-91.

Subhandu Mandal, K.C., Biswal and P.K., Jalna (2005). Yield, Economics, nutrient uptake and consumptive use of water by summer, greengram influenced by irrigation and Phosphorus application. 28(2):131-133.

\section{How to cite this article:}

Pole Shiva Kiran, Joy Dawson, Sunnam Hemanth Kumar and Bareddy Narendranath Reddy. 2020. Effect of Different Levels of Phosphorus and Biofertilizer Combination on Growth and Yield of Kharif Greengram (Vigna radiata L.). Int.J.Curr.Microbiol.App.Sci. 9(11): 28872891. doi: https://doi.org/10.20546/ijcmas.2020.911.349 